\title{
Р.М. Хренова-Шимкіна
}

\author{
Наџіональна академія державного управління при Президентові України, Україна
}

\section{ПРОСКТНА ДІЯЛЬНІСТЬ ОРГАНІВ ПУБЛІЧНОЇ ВЛАДИ ЯК ОБ'ЄКТ НАУКОВОГО ДОСЛІДЖЕННЯ}

В статті розглянуто сутність та зміст проєктної діяльності як об'єкту наукового дослідження. Акцентовано увагу на тому, щчо проєктна діяльність органів публічної влади має ряд ознак, серед яких ключовими є його регламентація (обмеженість у часі), відповідність запитам громади, спрямованість на розвиток територіальної одиниці та відкритість. Автор також запропонував схему проєктної діяльності та розглянув усі компоненти ичього процесу. Окрему увагу приділено чинникам покращення ефективності реалізачіі проєктів: знанневій компоненті - людському капіталу, моніторингу процесу, джерелам фінансування та комунікаціям. Також у статті представлена авторська класифікація проєктної діяльності органів публічної влади.

Ключові слова: проєктна діяльність, органи публічної влади, людський капітал, комунікації, моніторинг.

\section{Постановка проблеми}

Держава, як складна система, що забезпечує соціально-економічний розвиток, постійно стикається $з$ викликами глобального або місцевого рівня. Відтак органи публічної влади повинні мати дієві інструменти аби вирішувати бідь-які проблеми, долати перешкоди щодо досягнення стратегічних цілей державою. Традиційним інструментом вважають нормотворчість. Переоцінити важливість такої діяльності неможливо, адже вона дозволяє функціонувати усім складовим механізму державного управління. Проте традиційна модель не $\epsilon$ повороткою. Пов'язано це 3 тим, що подекуди технології прийняття рішень ускладнені й вимагають багато часу для підготовки та узгодження рішень, а також орієнтовані на усереднені показники, зокрема, щодо потреб населення. Як наслідок, рішення може не враховувати особливі потреби громади чи бути запізнілим. Тож наразі усе більшого поширення набувають інструменти проєктної діяльності органів публічної влади, оскільки вони більше орієнтовані на вирішення конкретних проблем окремої громади чи території. У той же час, незважаючи на те, що проєктна діяльність $є$ достатньо дослідженою у науковому колі, мало дослідженими залишаються питання щодо реалізації проєктів в умовах цифрової економіки, особливостей проєктної діяльності органів публічної влади в окремих сферах економіки, соціальне проєктування.

\section{Аналіз останніх досліджень і публікацій}

Серед чисельних робіт 3 питань державного управління в Україні, варто відзначити роботи
В.Бабаєва [15]., Т. Безверхнюк, С. Бушуєва, В. Вакуленко, Т.Торгало [25], О. Федорчак, Н.Чалої [29], А. Чемерис [30], Ю.Шаров [16], та ін. При цьому, Бушуєв С. зосередив увагу на сучасних підходах управління проєктами, програмами в освіті, Федорчак О. доводить універсальність проєктного менеджменту, як інструменту управління будь-яким напрямом (від освіти та охорони здоров'я до оборони). Чала Н. наголошує на важливості реалізації проєктів, пов'язаних 3 якістю та розвитком життя населення, а Чемерис А. представив передові світові практики реалізації державних проєктів та можливості використання цього досвіду в Україні. Разом 3 тим, проєктна діяльність органів влади видозмінюється під впливом глобалізації, поступами 4 промислової революції. Як зазначає Хмаммершмід [7, с.5], існують країни, де проєктна діяльність $є$ дуже жвавою, але вона трансформувалася у New Public Management (NPM). Для України можливості запровадження такого передового досвіду європейських країн потребують дослідження. Тож дослідження проєктної діяльності як об'єкта наукового дослідження є вкрай актуальним.

Метою статті $\epsilon$ дослідження проєктної діяльності органів публічної влади як об'єкту наукового дослідження.

\section{Виклад основного матеріалу}

Як ми вже зазначили, розробка політики є базовою функцією та стратегічним завданням уряду, оскільки через нормотворчість створює правила діяльності для бізнесу та умови зростання добробуту населення. Демократичні інструменти дозволяють зробити процес формування політики, 
прийняття рішень більш відкритим для суспільства, тож має бути підтриманим під час відповідних консультацій. Однак усі ці процеси $\epsilon$ довготривалими, «дорогим, трудомісткими й вимагають значних зусиль» [9].

Як альтернативу, було запропоновано використовувати проєктний менеджмент. Поява New Public Management (далі NPM) по всьому світу, сприяла включенню проєктного менеджменту в державне адміністрування. Деякі автори характеризуючи NPM, акцентували на широких його можливостях щодо забезпечення ефективності державного управління та необхідності i децентралізації, сприяння розвитку бізнесу шляхом покращення надання державних послуг [13]. Тож результатом поширення NPM стала зміна ролі держави та її уряду: 3 відстороненого контролера чи адміністратора вона перетворилися на джерело надання державних послуг [14] та учасника соціальних чи фінансово-економічних проєктів задля вирішення актуальних завдань. Зазначимо, що сучасна практика державного управління грунтується на принципах проєктування, які «вшиті» у проєктний менеджмент. У той же час, деякі закордонні вчені ставлять під сумнів ефективність такого підходу до виконання державою властивих їй функцій [2]. Враховуючи різні позицій в науковому колі, ми схиляємося до думки Аткінсона, який чітко розмежував державне управління та проєктну діяльність органів публічної влади. Зокрема, він визначив ознаки проєктної діяльності: «управління проєктами полягає в тому, що проєкт обмежений часом i грошима, i ці обмеження, як правило, розглядаються як фіксовані або як дві сторони трикутника, на яких можна зазначити якість» [2].

Досліджуючи сутність проєктної діяльності органів публічної влади, ми з'ясували спільні та суперечливі трактування цієї діяльності. Наприклад, у базовій книзі управління проєктами Американської асоціації стандартів (Project Management Institute) проєкт визначено, як тимчасові зусилля, що здійснюються для створення унікального продукту чи послуги, протягом визначеного часу [1 , с. 4-5]. Кукі-Девідс також наголошує на тому, що проєктна діяльність має часові обмеження, але акцентує на тому, що це сукупність людських зусиль які спрямовані на створення або зміну товару чи послуги таким й, таким чином, досягнення корисних змін [4, с. 20], а у подальших своїх публікаціях ефективність проєктів зумовлює ціннісними орієнтаціями [3]. Охара також звертає увагу на особливість проєктної діяльності, як такої, що має на меті створення нових цінностей, яке завершується в «заданий або погоджений термін та 3 обмеженнями, щодо ресурсів й ураховуючи зовнішні обставини» $[10$, с. 15]. Підсумовуючи різні погляди щодо сутності та ознак проєктної діяльності органів публічної влади, автор виокремив ключові ознаки проєктної діяльності органів публічної влади:

- регламентація (обмеженість у часі) - проєкт триває визначений період часу, який оговорюють замовник і виконавець. Це означає, що проєкт має бути попередньо продуманим (у т.ч. щодо забезпеченості матеріальними ресурсами), економічно обгрунтованим, а заходи, котрі прописані - реальними до виконання та такими, що їх можна оцінити;

- відповідність запитам громади - проєкт готується під конкретне завдання, має відповідати визначеним цілям, а також задовільнять потреби громади. Це означає, що проєкт, його заходи та результати, яких планується досягти, мають бути соціально значимі, узгодженими 3 потребами громади;

- спрямованість на розвиток територіальної одиниці - результативність проєкту оцінюється за критерієм розвитку. Тобто проведені заходи, передбачені даним проєктом, повинні бути спрямовані на забезпечення чи стимулювання сталого розвитку територіальної одиниці;

- $\quad$ відкритість - жоден з проєктів не може бути «закритим», ставити під сумнів мотиви виконавців. Маємо на увазі, що проєкт має реалізовуватися таким чином, аби уникати будь-яких корупційних схем чи виникнення конфлікту інтересів.

Дослідимо більш глибоко сутність поняття «проєктний менеджмент». Дана дефініція має декілька трактувань: від розуміння його як бізнеспроцес до соціально орієнтованої діяльності (табл.1)

3 таблиці бачимо, що вони зводять проєкт до певного завершеного бізнес-процесу. Відтак, виникають специфічні його ознаки: тривалість, результативність, ін. Водночас, проєкт можна розуміти як певний інструмент до вирішення завдань, що стоять перед державою. 3 цієї позиції взаємозв'язок проєктів 3 діяльністю органів публічної влади, уряду може бути простежений через реалізацію програм на державному рівні або заходів щодо виконання узятих зобов'язань місцевими органами влади. Зокрема, Федорчак О.В зазначає, що програми i проєкти дуже важко відокремити один від одного, оскільки програма може складатися 3 декількох [26]. Тісний зв'язок та необхідність використання проєктного менеджменту досліджували Бабаєв В.М. і Торкатюк B.I. Так, автори стверджують наступне:

- розробка та втілення державних програм вимагає застосування інструментів проєктного менеджменту; 
- проєктний підхід забезпечує ефективне вирішення проблем контролю термінів, витрат та ефективності;
- досягається підвищення контролю 3 боку громадськості, щодо оцінки виконаних завдань. [15]

Таблиця 1

Дослідження поняття «проєкт» в науково-практичних публікаціях*

\begin{tabular}{|c|c|}
\hline Джерело інформації & Сутність проєкту \\
\hline $\begin{array}{l}\text { Німецький інститут стандартів - Deutsches Institut für } \\
\text { Normung (DIN) [24]. }\end{array}$ & $\begin{array}{l}\text { визначає проєкт як цілеспрямовану діяльність } \\
\text { тимчасового характеру, призначену для } \\
\text { створення унікального продукту або послуги; при } \\
\text { цьому реалізації проєкту притаманні специфічні } \\
\text { способи організації робіт і управління }\end{array}$ \\
\hline $\begin{array}{l}\text { Інститут проєктного менеджменту у США (Project } \\
\text { Management Institute) [23]. }\end{array}$ & $\begin{array}{l}\text { визначає проєкт як підприємницьку діяльність, } \\
\text { котра відповідає встановленими цілями, містить } \\
\text { опис шляхів досягнення цієї мети та методологію } \\
\text { оцінювання результатів по завершенню проєкту }\end{array}$ \\
\hline Павлова С.I. [22]. & $\begin{array}{l}\text { Проєкт розглядається як певний задум, бачення, } \\
\text { бажаний стан та необхідні засоби для його } \\
\text { досягнення } \\
\text { або реалізації. }\end{array}$ \\
\hline Федорчак О.В. [27]. & $\begin{array}{l}\text { унікальне починання, одноразова послідовність } \\
\text { дій, комплекс заходів на досягнення певної мети. }\end{array}$ \\
\hline Довгань Л. Є., Мохонько Г.А., Малик І.П. [17]. & 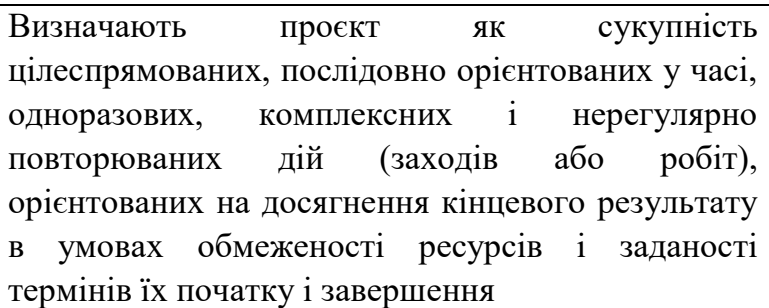 \\
\hline
\end{tabular}

розроблено автором

Отже, в статті ми розглядаємо проєктну діяльність як важливу частину державного управління, особливо через реалізацію цілей розвитку держав та їхніх органів публічної влади, постійне поліпшення якості функціонування та послуг. Тобто проєктна діяльність - це процес, що включає послідовне виконання заходів, об'єднаних спільною метою, які мають чітко визначені початок і завершення реалізації й у результаті виконання яких буде створено нові блага, корисні для певної громади чи суспільства у цілому. Схематично процес проєктної діяльності представлено на рис.1.

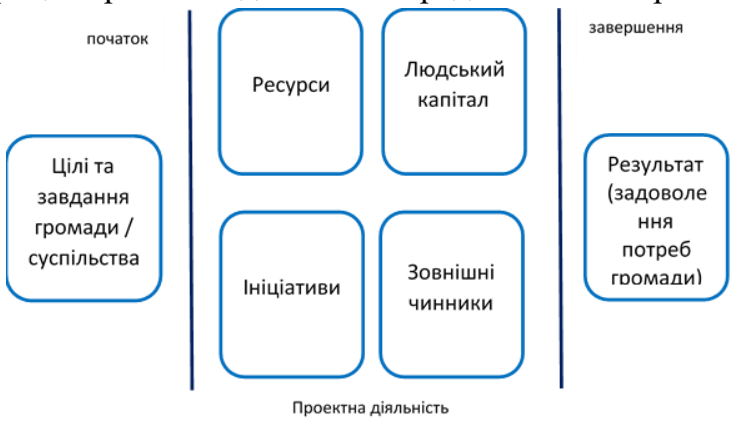

Рис. 1. Схема проєктної діяльності, як об’єкту " розроблено автором
3 рисунку 1 видно, що проєктна діяльність органів публічної влади підпадає під загально прийняту у менеджменті модель SMART та орієнтована на ініціативи зацікавлених сторін.

Розглянемо детальніше усі елементи проєктної діяльності. По-перше, будь-який проєкт має чітко визначені терміни реалізації - початок і завершення. По-друге, цілі і завдання такої діяльності продиктовані потребами суспільства чи громади (в залежності від того, на якому рівні буде реалізовано проєкт) ${ }^{1}$. На сучасному етапі розвитку Україні, найбільш актуальними є Цілі сталого розвитку [28]. Відтак, залежно від цілей автор виокремив основні види проєктної діяльності:

- соціального спрямування (вирішення завдань щодо подолання бідності, збереження здоров'я населення, дотримання прав людини, забезпечення благополуччя та безпеки дітей, тощо);

- інфраструктурного характеру (розвиток мережі громадського транспорту, покращення комунального обслуговування, покращення

\footnotetext{
${ }^{1}$ Автори виокремлюють проєкти на рівні громад та окремих територіальних одиниць та на державному рівні
} 
логістики щодо доріг, розташування і кількості закладів дошкільної освіти, тощо);

- екологічного спрямування (захист довкілля, збереження заповідників, будівництво очисних споруд та запровадження кращих очисних технологій, розвиток вторинного виробництва, тощо);

- інвестиційного характеру (розбудова зон рекреації та туризму, поширення цифрових технологій в обслуговування населення (SMART технології), реалізація спільних проєктів 3 бізнес компаніями в рамках програм корпоративної соціальної відповідальності та державно-приватного партнерства, ін.)

Враховуючи різність цілей та завдань, що стоять перед органами публічної влади, проєктна діяльність яку вони реалізують, як правило, вимагає об'єднання не тільки власних зусиль, але й бізнесу і громади. Зокрема, в рамках проєктної діяльності варто виділити проєкти державно-приватного характеру, які мають суттєвий вплив на досягнення як економічних, так i соціальних цілей територіальних громад. Наприклад, завдяки підписаному Меморандуму між Міністерством регіонального розвитку, будівництва та ЖКГ України, Посольством Литовської Республіки в Україні та Agriteam Canada Consulting LTD створені Регіональні центри проєктного менеджменту, котрі у подальшому сприятимуть реалізації проєктів, підсилять регіональні управлінські команди, а також спростять залучення інвестицій на рівні місцевого самоврядування [18].

По-третє, результат проєктної діяльності - це нові продукти чи послуги. При цьому, результат має чітко корелюватися 3 поставленими цілями. Тобто, якщо метою проєкту було розвиток соціального підприємництва в регіоні, то результатом можуть бути створені соціальні підприємства чи зареєстровані нові підприємці, рівень обізнаності громади щодо практики соціальної підприємницької діяльності (юридичні, фінансові, інші аспекти роботи). Таким чином, проєктна діяльність може визнаватися ефективною лише за умови досягнення реальних результатів, котрі можна виміряти, оцінити. Це ще одна особливість проєктної діяльності органів публічної влади.

Основу проєктної діяльності формують ініціативи зацікавлених сторін, ресурси та людський капітал. Крім того, поєднання усіх компонентів обов'язково має бути оцінено щодо можливих наслідків та ризиків для громади, навколишнього середовища. Так, Козаченко Т.П. однією з ознак проєктної діяльності органів публічної влади називає оцінку ризиків [20]. У той же час вважаємо, що у разі тотожності цілей проєкту громади Цілям сталого розвитку, то соціальні ризики чи ті, які пов'язані зі шкодою оточуючому середовищу, не можуть виникнути. Скоріше можна говорити про ризики невиконання проєкту через певні перешкоди.

Як ми вже зазначили, проєктна діяльність реалізується на різних рівнях. Для України характерними $є$ рівень держави, адміністративнотериторіальної одиниці, окремої громади. Як правило, найбільш фінансово потужними $є$ ті, що реалізуються на державному рівні. Проте найбільш відповідальними та соціально орієнтованими є ті, що реалізуються на рівні міст ${ }^{2}$. При чому така практика притаманні й світовим лідерам.

Для прикладу розглянемо досвід Канади. Задля покращення ефективності проєктів, котрі реалізує публічна влада, було створено спеціальну службу Консультативну раду 3 управління проєктами (РМАС). Її заданням є дослідження відповідності поданого проєкту нормам законодавства, політиці казначейства, порівняння вартості та можливих зисків від реалізації даного проєкту. Крім того, як зазначено на офіційному сайті PSPC Services, PMAC ділиться кращими практиками подання і реалізації проєктів, сприяє використанню кращих інструментів управління проєктами, а також здійснює нагляд за тим, щоб державна служба закупівельна Канади постійно оновлювалася новими проєктами [12]. Подібна практика існує в європейських країнах. Зокрема, Свропейська Комісія створила фонд підтримки проєктів, спрямованих на сталий енергетичний розвиток регіонів, міст, муніципалітетів. Тобто відбір проєктів відбувається за принципом відповідності цілям сталого розвитку, зокрема в сфері енергектики. Тож такі проєкти є міжнародними i реалізуються в рамках програми Horizon 2020 Energy Efficiency [11].

Вивчаючи проєктну діяльність органів публічної влади, як об'єкт наукового дослідження, відзначимо, що після визначення та усвідомлення цілей, важливо розпочинати безпосередні дії щодо реалізації проєкту. Тож наступним кроком реалізації проєкту є поєднання ініціативи громади чи бізнесу 3 ініціативами органів публічної влади. Але ініціативи - це лише заявка на проєкт. Сам проєкт буде можливо реалізувати лише за певних умов: наявності ресурсів, якісного людського капіталу та правильно вибудованих комунікацій. У різі зникнення будь-якого елементу цього трикутника, проєкт не зможе існувати.

Розглянемо вище зазначені складові успішної проєктної діяльності. Ресурси - це традиційна зрозуміла компонента, яка включає фінансову,

\footnotetext{
2 Детальніше про фінансування проєктів можна ознайомитися на порталі IFls projects за посиланням: https://proifi.gov.ua/?p=index
} 
знаннєву та часову компоненту. У цьому контексті джерелом фінансових ресурсів можуть виступати кошти держави, місцевих громад, бізнесу чи благодійних установ та фондів. Таким чином, сума коштів та умови їх надання будуть продиктовані гарантом проєкту чи його замовником. Наприклад, джерелом фінансових ресурсів може бути місцевий бюджет. Зокрема, відповідно до проєкту 3 покращення енергоефективності, заклади освіти Вільшанської ОТГ Житомирської області переобладнано котлами (проєкт розраховано на 2 роки), котрі дозволять знизити залежність від природного газу, що дасть можливість громаді економити до 230 тис. грн. на рік [19]. Тож замовником i інвестором виступила місцева адміністрація й кошти були виділені 3 місцевого бюджету. У разі, коли бізнес $є$ інвестором у розвиток громад, то він визначає напрямки витрат цих коштів. Наприклад, компанія НАЕК «Енергоатом» постійно інвестує у соціальний розвиток міст-супутників, де розташовані АЕС. Як зазначає Григорій Муляр, директор 3 кадрів та соціальних питань цієї компанії, у 2018 році інвестиції до місцевих громад склали 456,9 млн грн, що на 23,7 \% більше, ніж у 2017 році (кошти, що виділялися були спрямовані на підтримку місцевої інфраструктури) [21]. Але незалежно від джерела фінансування проєкту, він має жорстко контрольовані часові рамки, фінансові ліміти та затверджені напрямки реалізації коштів (тобто прописано адресат). Саме це дає можливість оцінити чи ефективний проєкт, чи вирішив проблеми тієї чи іншої громади, міста, тощо.

Разом $з$ тим, вважаємо, що головним чинником ефективної проєктної діяльності $€$ знаннєва компонента, що залежить від людського капіталу. Те, на скільки освічені, компетентні учасники проєктної діяльності, визначає результативність проєкту: вона може бути вищою, а ризики під час реалізації мінімізовані. Особливо роль людського капіталу усвідомлюється в країнах, де цифрова економіка найбільш розвинена. За останніми дослідженнями Делойт, 71\% респондентів у державному секторі вважають, що лідери повинні розуміти нові технології, щоб бути ефективними [5]. Тому керівникам та лідерам проєктів, що реалізуватимуться спільно державою та громадськістю, мають бути притаманні наступні якості: уміння управляти персоналом, у т.ч. дистанційно, 3 використанням сучасних IT технологій, знання та уміння застосовувати адекватні інструменти мотивації та посилення залученості учасників проєкту, уміння здійснювати комунікації та формувати бренд органів публічної влади.
Якісні комунікації між усіма учасниками проєкту передбачають їхню транспарентність, постійність, своєчасність, повноту та достовірність. Тут важливо чітко розмежовувати комунікації органів державної влади з громадами, суспільством як способу надання інформації, обміну думками й способом можливого впливу на прийняття рішень людьми. Маємо на увазі ситуації, коли де-які дії органів влади можуть бути сприйняті суспільством негативно. Наприклад, у разі коли місцева влада спрямовує свою комунікацію до батьків аби переконати їх у необхідності вакцинації дітей, щоб запобігти розповсюдженню вірусів (як то грип), громадська позиція може бути іншою. Таке може статися, коли медіа доводять недостовірну або неповну інформацію про стан захворюваності, способи лікування й, як наслідок, певна частка батьків не погоджуються проводити заходи 3 посилення імунітету дитини. Досліджуючи даний аспект реалізації проєктів органами влади, ми відстежили певні протиріччя, що існують й у європейських країнах. Там також немає чіткого розмежування між «що таке добре, а що ні». Зокрема, на такому наголошують Фредріксон М та Паласс Дж. Досліджуючи умови співпраці органів влади та 3MI, ними були проаналізовані різні чинники, котрі впливають на ефективність комунікацій. Зокрема, автори доводять, що ЗМІ відіграють важливу роль, коли інформація поширюється по всьому суспільству, і що хороші стосунки зі ЗМІ можуть допомогти та підтримати амбіції організацій щодо інформування та управління ними [6]. Автор у своїх емпіричних дослідженнях також дійшов висновку про те, що надання повної, вичерпної та достовірної інформації сприяє зростанню довіри до проєктної діяльності органів публічної влади й громадськість підтримуватиме такі ініціативи.

Аби подолати прірву недовіри, також важливо розуміти: самі комунікації передбачають не тільки спілкування, але й інформування про наміри, результати аналізу, моніторингу, а також роздуми та пропозиції щодо покращення змісту проєкту, інструментарію його реалізації. Тож у всьому різноманітті аспектів комунікації, важливе місце посідає моніторинг процесу. Оскільки принципами демократичного управління на місцевому рівні $\epsilon$ : відсутність корупції, залученість громадськості до процесів прийняття рішень, урахування етичних норм, відкритість та прозорість, верховенство права, компетентність та інноваційність, соціальна згуртованість, а також підзвітність, тому автор вважає, що моніторинг дозволяє зробити комунікації та взаємодію органів публічної влади з громадою та бізнесом більш транспарентними, відкритими та ефективними. Ми також погоджуємося з висновками Кресналійської Г. про те, що моніторинг проєктів, 
котрі реалізують органи публічної влади, має бути спрямовано на підтримку процесу прийняття управлінських рішень [8], адже оперативна інформація щодо вимірювання досягнення цілей проєкту та ефективності використовуваних заходів дозволить вчасно вносити корективи й покращити результат.

Окремим елементом схеми проєктної діяльності органів публічної влади автор визначає зовнішні чинники. До них необхідно віднести бренд (визнання) країни на політичному полі у глобальному світі, стабільність законодавства та сприятливий бізнес та інвестиційний клімат, міграційні або інші дестабілізуючі процеси (військові операції, фінансова криза, санкційні війни, епідемії, інше), а також сформованість різних інституцій та інститутів. Названі чинники важко оцінити, проте вони можуть суттєво вплинути як на хід реалізації проєкту та і на появу ініціатив, пов'язаних 3 тією чи іншою ситуацією в даній місцевості, країні, світі. Наприклад, бойові дії на сході стимулювали поширення проєктів щодо підтримки військових, забезпечення їх необхідними речами, адаптації воїнів до мирного життя.

Крім того, досліджуючи проєктну діяльність як наукову категорію, вважаємо за доцільне навести наступну класифікацію проєктів (рис.2).

Щодо класифікації проєктів за цілями, то варто звернути увагу на таке. Метою проєкту можуть бути різні аспекти задоволення інтересів та потреб суспільства в цілому або окремої громади. Оскільки ці цілі можливо досягти завдяки впровадженню нових ІТ-технологій, то такі проєкти $є$ ITтехнологічними (наприклад проєкти щодо інтерактивних карт, сервісів для пошуку інформації, ін.). У разі, коли метою проєкту є підвищення рівня освіченості населення щодо певної проблематики й необхідно проводити освітні заходи, тренінги, навчання, то такі проєкти за цілями є просвітницькі. Проєкти - дослідження, це ті, що спрямовані на 3'ясування першопричин якогось явища або пошук способів задоволення потреб суспільства чи громади. Так, для вирішення завдання подолання бідності, важливо оцінити глибину бідності та виявити найбільш уразливі категорії людей, з'ясувати причини бідності цих категорій осіб. Тому за громадської ініціативи наукова установа або громадська організація може реалізувати проєкт дослідження бідності, наприклад, певного міста, який у подальшому стане основою розробки та прийняття програми розвитку цього міста або проєкту соціальної допомоги тощо. Інноваційні проєкти мають певну особливість.

Вони за змістом містять нові підходи до вирішення проблеми, спрямовані на створенні нового продукту чи послуги. Здебільшого на сьогодні, інноваційні проєкти пов'язані зі збереженням екології та енергозбереженням. Зокрема, як на державному, так i місцевому рівні поширена практика реалізації проєктів 3 переходу на альтернативні види опалення, поширення «зеленої енергетики». Інвестиційні ж проєкти за характером мають ознаки економічної корисності, відтак, часто пов'язані зі створенням робочих місць. Таким проєктом може бути створення соціального підприємства, реалізація інфраструктурного проєкту, реформування управління процесом чи організацією, iH.

За результатами проєкти можуть бути: економічні, соціальні та організаційні. За даним критерієм оцінюється відповідність та рівень досягнення цілей: економічних, соціальних та організаційних. Так, у разі реалізації проєкту зі проведення навчання щодо розвитку підприємницьких здібностей, отримуємо економічні зиски через покращення ситуації у сфері самозайнятості та зайнятості населення. У цьому випадку саме економічні зиски більш відчутні, їх можливо оцінити. Проте такий проєкт несе соціальні результати, але вони не настільки впливають ра зміну рівня виконання поставлених завдань щодо, наприклад, зниження безробіття. Так само, реалізуючи проєкт 3 обладнання спортивних майданчиків, у результаті очікується надати можливості (зробити доступним для усіх) і посилити відповідальність кожного за власне здоров'я та членів своєї родини. Очевидним є те, що соціальні завдання - досягнення цілей сталого розвитку у сфері охорони здоров'я $\epsilon$ оцінюваним та вагомим. Разом 3 тим, можемо мати й економічні зиски через зменшення витрат від тимчасової непрацездатності населення(через хвороби, котрі виникають через неправильний спосіб життя). Прикладом організаційного проєкту $є$ досягнення соціальноекономічних цілей шляхом реформування організаційних структур, зміни підходів до вирішення проблем членів громади. Так, реалізувавши проєкт зі запровадження електронних кабінетів споживачів послуг комунального господарства, очікується знизити навантаження на працівників цієї сфери, зробити їхню роботу більш ефективною (зокрема, довідки можуть друкуватися он-лайн, інформація про сплату рахунків буде доступною у будь-який час, для населення стане можливим сплачувати за послуги без черг, тощо) й таким чином сприяти посиленню рівня довіри до таких установ. Тож даний проєкт, змінюючи організацію процесу надання послуг, дозволяє отримати організаційний ефект, що проявлятиметься як у економічних (зокрема, економія часу, зниження трудозатрат) так і соціальних (лояльність клієнтів) позитивних зрушеннях. 


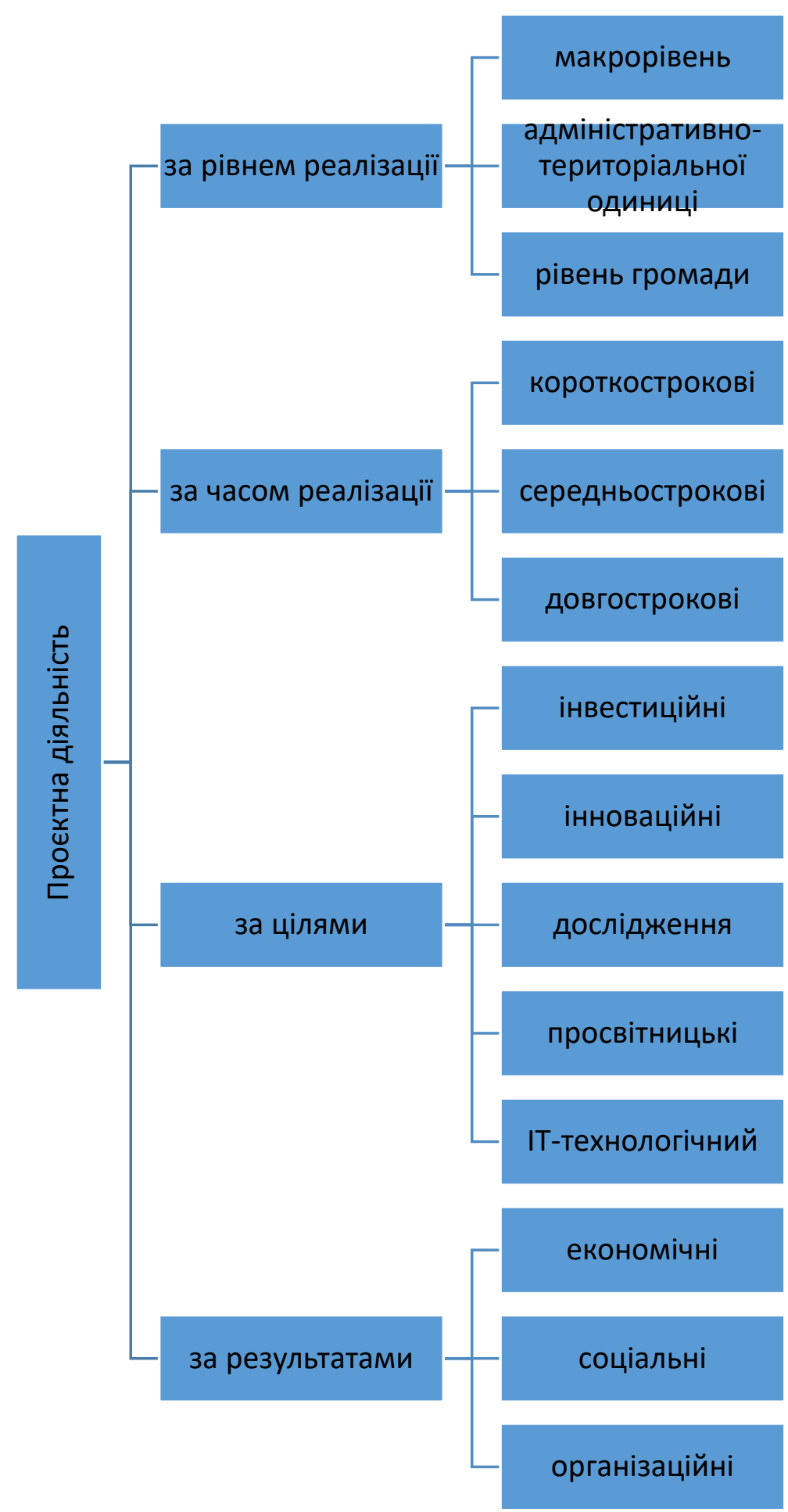

Рис. 2. Класифікація проєктної діяльності, як об’єкту дослідження за різними критеріями ${ }^{*}$ * розроблено автором

\section{Висновки}

Для України, незважаючи на те, що проєкти, що реалізуються, максимально наближені до світової практики, досвід використання проєктної діяльності органів публічної влади $є$ незначним. Разом 3 тим в умовах трансформації економіки під впливом цифровізації та конфлікту на сході країни, підходи та вимоги до проєктів змінюються, також

$$
\text { 3'являються нові потреби громад щодо }
$$$$
\text { кібербезпеки, навчання, соціального }
$$
підприємництва, волонтерства, зеленої енергетики, тощо. Усе це потребує переосмислення та дослідження сутності, ознак, змісту проєктної діяльності органів публічної влади в нашій державі.

Запропоновані автором пропозиції щодо визначення ключових ознак проєктної діяльності органів публічної влади, дозволить здійснювати 
якісний відбір проєктів. Упровадження авторської схеми проєктної діяльності у практику сприятиме просуванню соціально та економічно обгрунтованих й корисних проєктів, дозволить подолати кризу недовіри до органів публічної влади та дозволить покращити результативність цих проєктів й знизити ймовірність появи ризиків невиконання.

\section{Література}

1. A Guide to the project management body of knowledge the standard p project management ANSI/PMI 99-001-2017 . (2017) Sixth Edition. Project Management Institute. Retrieved from

https://www.academia.edu/39204743/Guide_to_the_Project_ Management_Body_of_Knowledge_PMBOK_Guide_6th_Edi tion

2. Carter, P. (2019) Time tactics: Project managing policy implementation in a network. Time \& Society, 28(2), 721-742. Retrieved

from https://journals.sagepub.com/doi/pdf/10.1177/0961463X16682 517

3. Cooke-Davies, T. J, Crawford, L., Lechler, Th. (2009) Project management systems. Moving project management from an operational to a strategic discipline. Project Management Journal, 40(1), March 2009. Retrieved from https://www.researchgate.net/publication/27827186_Project_ management_systems_Moving_project_management_from_a n_operational_to_a_strategic_discipline

4. Cooke-Davies, T. J. (2001) Towards Improved Project Management Practice: Uncovering the evidence for effective practices through empirical research. PhD Thesis. Leeds Metropolitan University, Leeds. Retrieved from http://www.bookpump.com/dps/pdf-b/1121288b.pdf

5. Deloitte Human Capital (HC) Trends (2019). Government \& Public Services (GPS) Industry Breakout . Retrieved from https://www2.deloitte.com/content/dam/Deloitte/us/Document s/public-sector/us-2019-government-perspectives-human-

capital-trends-report.pdf

6. Fredriksson, M. , Pallas, J. (2018) Public Sector Communication. Retrieved from https://www.researchgate.net/publication/327879211_Public_ Sector_Communication

7. Hammerschmid, G. (n.d.) Public Management Reform: An Identity Project. Retrieved from https://www.researchgate.net/publication/249827892_Public_ Management_Reform_An_Identity_Project

8. Kresnaliyska, G. (2015) Monitoring of Public Policies - A Modern Tool of Good Governance. American International Journal of Contemporary Research, 5, 5, 43-47. Retrieved from

http://www.aijcrnet.com/journals/Vol_5_No_5_October_2015 16.pdf

9. Mirzaei, M., Mabin, V. J. (2017) Agile Project Management and Public Policy Development Projects: A case study from New Zealand. NZJABR, 15, 1, Retrieved from https://www.researchgate.net/publication/321145063_Agile_P roject_Management_and_Public_Policy_Development_Projec ts_A_case_study_from_New_Zealand

10. Ohara, Sh. (2005) A Guidebook of Project \& Program Management for Enterprise Innovation, I. Retrieved from https://articulospm.files.wordpress.com/2013/01/p2mguideboo kvolume1_060112.pdf

11. Project Development Assistance (PDA (n.d.)). Retrieved from https://ec.europa.eu/easme/en/projectdevelopment-assistance-pda

12. Project Management Handbook. (n.d.) Retrieved from https://www.tpsgc-pwgsc.gc.ca/biens-property/sngp-npms/ti-

it/ggp-pmh-pg1-eng.html

13. Pūlmanis, E. (2014) Public sector project management efficiency problems, case of Latvia. Regional Formation and Development Studies, 3 (11). Retrieved from https://www.researchgate.net/publication/271416985_PUBLI C_SECTOR_PROJECT_MANAGEMENT_EFFICIENCY_P ROBLEMS_AND_SOLUTIONS_CASE_OF_EU_MEMBER _STATE_-LATVIA

14. Žurga Gordana. (2018) Project managtment in public administration. TPM - total project management maturity model. The case of Slovenian public administration. Transylvanian Review of Administrative Sciences, 53, 144159. Retrieved from https://rtsa.ro/tras/index.php/tras/article/download/554/543

15. Бабаєв, В.М. Проєктний підхід в механізмі державного управління. [Електронний ресурс] / В.М. Бабаєв, B.I. Торкатюк. - Режим доступу http://eprints.kname.edu.ua/29745/1/50.pdf

16. Безуглий, Д.Г. Проєктний підхід в управлінні розвитком та співробітництвом укрупнених територіальних громад. [Електронний ресурс] / Д.Г. Безуглий, Ю.П. Шаров // Аспекти публічного управління. $\begin{array}{lllll}\text { № } & 6-7 & \text { (32-33). 2016. Режим доступу }\end{array}$ https://aspects.org.ua/index.php/journal/article/download/275 1274

17. Довгань, Л. С. Управління проєктами [Електронний ресурс] : Навчальний посібник. / Л.С. Довгань, Г.А. Мохонько, І.П. Малик - К.: КПІ ім.Ігоря Сікорського, 2017. - $420 \quad$ c. $\quad$ Режим доступу https://ela.kpi.ua/jspui/bitstream/123456789/19481/1/DMM_ UP_2017.pdf

18. За підтримки Канади та Литви в Украйні створять Регіональні иентри проєктного менеджменту. [Електронний ресурс] // Сайт "Дещентралізаџія». Режим docmyny https://decentralization.gov.ua/news/10633

19. Книга успіхів. Короткі історії про те, як децентралізація впливає на життя громад. [Електронний ресурс ] / 2020.2 -Режим доступу http://auc.org.ua/sites/default/files/library/knygauspihiv_O1_2 020web.pdf

20. Козаченко, Т.П. Публічне управління на засадах проєктного менеджменту: сучасний погляд. [Електронний ресурс] / Т.П. Козаченко // Держава та регіони. №2(62), 2018. Ст.50-55. Режим доступу http://pa.stateandregions.zp.ua/archive/2_2018/11.pdf

21. Нефінансовий звіт Енергоатом. [Електронний ресурс] / 2018. - Режим доступу http://nfr2018.energoatom.kiev.ua/ua/Spivrobitniki-tagromadi.php

22. Павлова, С. І. Проєктно-орієнтовані організачиї як розвиток методів управління підприсмством. [Електронний ресурс] / С.І. Павлова // Вісник ЖДТУ. Серія: Економічні науки. 2016. № 4 (78). С. 170-176. Режим доступy http://www.irbis-nbuv.gov.ua/cgibin/irbis_nbuv/cgiirbis_64.exe?I21DBN=LINK\&P21DBN=U 
$J R N \& Z 21 I D=\& S 21 R E F=10 \& S 21 C N R=20 \& S 21 S T N=1 \& S 21$ $F M T=A S P \_m e t a \& C 21 C O M=S \& 2 \_S 21 P 03=F I L A=\& 2 \_S 21 S$ TR=Vzhdtu_econ_2016_4_20

23. Офіиійний сайm Project Management Institute. [Електронний ресурс] -Режим доступу https://www.pmi.org/

24. Стандарт управління проєктом. DIN69901. [Електронний ресурс] - Режим доступу https://pmpractice.ru/knowledgebase/normative/projectstanda rts/din-69901/

25. Торгало, Т. Механізм формування $і$ реалізачіі проєктів регіонального розвитку: стан наукового розроблення. [Електронний ресурс] / T. Торгало // Public Administration and Local Government. №1(28). 2016. Режим docmyny http://www.dridu.dp.ua/vidavnictvo/2016/2016_01(28)/16.pdf 26. Федорчак, О. В. Інновачійні інструменти управління иільовими програмами і проєктами. [Електронний ресурс] / O.B. Федорчак - Режим доступу http://ifs.kbuapa.kharkov.ua/e-book/db/2012-2/doc/1/10.pdf

27. Федорчак, О. В. Проєктний підхід як інноваційний механізм державного управління. [Електронний ресурс] / O.B. Федорчак - Режим доступу http://academy.gov.ua/ej/ej3/txts/TEXNOLOGIYA/02-

FEDORCHAK.pdf

28. Цілі сталого розвитку 2016-2030. [Електронний pecypc] - Режим достуnyhttp://www.un.org.ua/ua/tsilirozvytku-tysiacholittia/tsili-staloho-rozvytku

29. Чала, Н.Д. Державне управління економічним розвитком України в глобальному просторі [Текст] : монографія / Н.Д. Чала - К.: Вид-во: ТОВ «Аграр Медіа Груп». 2012. $284 \mathrm{c}$.

30. Чемерис, А. Розроблення та управління проєктами у публічній сфері: європейський вимір для України. [Електронний ресурс] : Практичний посібник / А. Чемерис 2012. Режим доступу http://www.lvivacademy.com/vidavnitstvo_1/edu_44/fail/ch_1/ 24.pdf

\section{References}

1. A Guide to the project management body of knowledge the standard p project management ANSI/PMI 99-001-2017. (2017) Sixth Edition. Project Management Institute. Retrieved from

https://www.academia.edu/39204743/Guide_to_the_Project_

Management_Body_of_Knowledge_PMBOK_Guide_6th_Edi tion

2. Carter, P. (2019) Time tactics: Project managing policy implementation in a network. Time \& Society, 28(2), 721-742. Retrieved from https://journals.sagepub.com/doi/pdf/10.1177/0961463X16682 517

3. Cooke-Davies, T. J, Crawford, L., Lechler, Th. (2009) Project management systems. Moving project management from an operational to a strategic discipline. Project Management Journal, 40(1), March 2009. Retrieved from https://www.researchgate.net/publication/27827186_Project_ management_systems_Moving_project_management_from_a n_operational_to_a_strategic_discipline

4. Cooke-Davies, T. J. (2001) Towards Improved Project Management Practice: Uncovering the evidence for effective practices through empirical research. PhD Thesis. Leeds
Metropolitan University, Leeds. Retrieved from http://www.bookpump.com/dps/pdf-b/1121288b.pdf

5. Deloitte Human Capital (HC) Trends (2019). Government \& Public Services (GPS) Industry Breakout . Retrieved from https://www2.deloitte.com/content/dam/Deloitte/us/Document s/public-sector/us-2019-government-perspectives-human-

capital-trends-report.pdf

6. Fredriksson, M. , Pallas, J. (2018) Public Sector Communication. Retrieved from https://www.researchgate.net/publication/327879211_Public_ Sector_Communication

7. Hammerschmid, G. (n.d.) Public Management Reform: An Identity Project. Retrieved from https://www.researchgate.net/publication/249827892_Public_ Management_Reform_An_Identity_Project

8. Kresnaliyska, G. (2015) Monitoring of Public Policies - A Modern Tool of Good Governance. American International Journal of Contemporary Research, 5, 5, 43-47. Retrieved from

http://www.aijcrnet.com/journals/Vol_5_No_5_October_2015 /6.pdf

9. Mirzaei, M., Mabin, V. J. (2017) Agile Project Management and Public Policy Development Projects: A case study from New Zealand. NZJABR, 15, 1, Retrieved from https://www.researchgate.net/publication/321145063_Agile_P roject_Management_and_Public_Policy_Development_Projec ts_A_case_study_from_New_Zealand

10. Ohara, Sh. (2005) A Guidebook of Project \& Program Management for Enterprise Innovation, I. Retrieved from https://articulospm.files. wordpress.com/2013/01/p2mguideboo kvolume1_060112.pdf

11. Project Development Assistance (PDA (n.d.)). Retrieved from https://ec.europa.eu/easme/en/project-developmentassistance-pda

12. Project Management Handbook. (n.d.) Retrieved from https://www.tpsgc-pwgsc.gc.ca/biens-property/sngp-npms/tiit/ggp-pmh-pg1-eng.html

13. Pūlmanis, E. (2014) Public sector project management efficiency problems, case of Latvia. Regional Formation and Development Studies, 3 (11). Retrieved from https://www.researchgate.net/publication/271416985_PUBLI C_SECTOR_PROJECT_MANAGEMENT_EFFICIENCY_P ROBLEMS_AND_SOLUTIONS_CASE_OF_EU_MEMBER _STATE_-LATVIA

14. Žurga Gordana. (2018) Project managtment in public administration. TPM - total project management maturity model. The case of Slovenian public administration. Transylvanian Review of Administrative Sciences, 53, 144159. Retrieved from https://rtsa.ro/tras/index.php/tras/article/download/554/543

15. Babayev, V., Torkatyuk, V. (n.d.) Project approach in the mechanism of public administration. Retrieved from http://eprints.kname.edu.ua/29745/1/50.pdf

16. Bezugliy, D., Layers, Yu. (2016) A project approach in managing the development and cooperation of larger territorial communities. Aspects of Public Management, 6-7 (32-33). Retrieved from

https://aspects.org.ua/index.php/journal/article/download/275/274 17. Dovgan, L., Mohonko, G., Malik, I. (2017) Project Management: A textbook. - K .: Igor Sikorsky KPI, 420. Retrieved from

https://ela.kpi.ua/jspui/bitstream/123456789/19481/1/DMM_ UP_2017.pdf 
18. With the support of Canada and Lithuania, Ukraine will set up Regional Project Management Centers. (n.d.) Decentralization site. Retrieved from https://decentralization.gov.ua/news/10633

19. The book of successes. (2020) Short stories about how decentralization affects the lives of communities. Retrieved from

http://auc.org.ua/sites/default/files/library/knygauspihiv_01_2 020web.pdf

20. Kozachenko, T. (2018) Public management based on project management: a modern perspective. State and Regions, 2 (62), 50-55. Retrieved from

http://pa.stateandregions.zp.ua/archive/2_2018/11.pdf

21. Non-financial report of Energoatom. (2018) Retrieved from http://nfr2018.energoatom.kiev.ua/en/Spivrobitniki-tagromadi.php

22. Pavlova, S. (2016) Design-oriented organizations as development of enterprise management methods. Journal of ZhSTU. Series: Economic Sciences, 4 (78), 170-176. Retrieved from http://www.irbis-nbuv.gov.ua/cgibin/irbis_nbuv/cgiirbis_64.exe?I21DBN=LINK\&P21DBN=U $\mathrm{JRN} \& Z 21 \mathrm{ID}=\& \mathrm{~S} 21 \mathrm{REF}=10 \& \mathrm{~S} 21 \mathrm{CNR}=20 \& \mathrm{~S} 21 \mathrm{STN}=1 \& \mathrm{~S} 21$ FMT $=$ ASP_meta\&C21COM=S\&2_S21P03=FILA=\&2_S21S TR=Vzhdtu_econ_2016_4_20

23. Project Management Institute official website. (n.d.) Retrieved from https://www.pmi.org/

24. Project management standard. DIN69901. (n.d.) Retrieved from

https://pmpractice.ru/knowledgebase/normative/projectstandar ts/din-69901/

25. Torgalo, T. (2016) Mechanism of formation and realization of regional development projects: state of scientific development. Public Administration and Local Government, 1 (28). Retrieved from http://www.dridu.dp.ua/vidavnictvo/2016/2016_01(28)/16.pdf 26. Fedorchak, O. (n.d.) Innovative tools for managing targeted programs and projects. Retrieved from http://ifs.kbuapa.kharkov.ua/e-book/db/2012-2/doc/1/10.pdf

27. Fedorchak, O. (n.d.) The project approach as an innovative mechanism of public administration. Retrieved from http://academy.gov.ua/ej/ej3/txts/TEXNOLOGIYA/02FEDORCHAK.pdf

28. Sustainable Development Goals 2016-2030. (n.d.) Retrieved from http: //www.un.org.ua/en/tsili-rozvytkutysiacholittia/tsili-staloho-rozvytku

29. Chala, N. (2012) Public Administration of Economic Development of Ukraine in the Global Space: monograph - K $\therefore$ Issue: Agrar Media Group LLC, 284.

30. Chemerys, A. (2012) Project development and management in the public sphere: a European dimension for Ukraine : A Practical Guide. Retrieved from http://www.lvivacademy.com/vidavnitstvo_1/edu_44/fail/ch_1 124.pdf

Рецензент: доктор наук 3 державного управління, доцент Н.I. Олійник, Національна академія державного управління при Президентові України, Київ, Україна

\section{Автор: ХРЕНОВА-ШИМКІНА Ріпсіме Миколаївна \\ аспірантка кафедри економічної політики та врядування \\ Національна академія державного управління при Президентові України \\ E-mail-khg@kname.edu.ua}

\section{PROJECT ACTIVITIES OF PUBLIC AUTHORITIES AS OBJECTS OF SCIENTIFIC RESEARCH}

Ripsime Khrenova-Shymkina

National Academy for Public Administration under The President of Ukraine, Ukraine

The article deals with the nature and content of project activity as an object of scientific research. It is determined that the project management toolkit provides opportunities for ensuring the efficiency of public administration and the need for its decentralization, facilitating business development by improving the provision of public services, while reducing their cost and complexity. The essence of the concept of project management has been investigated and the relationship of projects with the activities of public authorities, the government, which can be traced through the implementation of programs at the state level or measures to fulfill the commitments undertaken by local authorities, has been identified. Attention is drawn to the fact that the project activity of public authorities has a number of features, among which the key are its regulation (time constraint), compliance with community requests, focus on territorial unit development and openness. The author also suggested a scheme of project activity and considered all components of this process. Particular attention is paid to the factors that improve the effectiveness of project implementation: the knowledge component - human capital, process monitoring, sources of funding and communications. The article also presents the author's classification of the project activity of public authorities, depending on the goals, the main types of project activity were separated: social orientation (solving problems of overcoming poverty, preserving the health of the population, observing human rights, ensuring the well-being and safety of children, etc.); infrastructural character (development of public transport network, improvement of public services, improvement of logistics on roads, location and number of pre-school educational institutions, etc.); environmental orientation (environmental protection, conservation of reserves, construction of treatment plants and introduction of the best treatment technologies, development of secondary production, etc.); investment nature (development of recreation and tourism areas, the spread of digital technologies in public services (SMART technologies), implementation of joint projects with business companies within the framework of corporate social responsibility programs and public-private partnerships, etc.).

Keywords: project activity, public authorities, human capital, communications, monitoring. 